\title{
The Determinants of Life Insurer's Growth for a Developing Insurance Market: Domestic vs Foreign Insurance Firms
}

\author{
Joseph J. Tien ${ }^{\mathrm{a}}$ and Sharon S. Yang ${ }^{\mathrm{b}}$ \\ ${ }^{a}$ Department of Insurance, Tamkang University, 151 Ying-Chuan Rd., Tamsui, Taipei County 251, Taiwan. \\ E-mail: jilltien@mail.tku.edu.tw \\ ${ }^{\mathrm{b}}$ Department of Finance, National Central University, Taoyuan 116, Taiwan. \\ E-mail: syang@ncu.edu.tw
}

The relationship between firm growth and firm characteristics has been a critical issue for insurers. This study examines the determinants of firm growth and tests Gibrat's law of life insurance company expansion in the context of the young but fast-growing insurance market for both domestic and foreign firms in Taiwan. By using Heckman's two-stage regression, our empirical results reveal that Gibrat's law does not hold for either domestic or foreign life insurers during the period from 1996 to 2007. Smaller life insurers achieve greater growth than larger ones in the booming economy. Furthermore, factors such as age, cross-marketing and product diversification show different effects on growth between domestic and foreign firms.

The Geneva Papers (2014) 39, 1-24. doi:10.1057/gpp.2013.6

Keywords: firm growth; firm age; firm size; Gibrat's law

Article submitted 12 April 2011; accepted 21 January 2013; published online 20 March 2013

\section{Introduction}

The determinants of life insurers' growth are critical factors for their operations. Many factors, such as lagged asset size, age, profitability, expense ratios, product diversification and marketing channels influence life insurers' growth. As the trend of globalisation continues, many life insurers from Western countries have extended their businesses overseas to the booming economies of developing countries. However, the factors that affect domestic firm growth could differ from those that influence foreign firms, due to differences in their cultural backgrounds, management styles and product design innovations. Previous studies have showed that foreign investments could have significant influences on local insurance market. ${ }^{1}$ Thus, examining different effects on the growth of domestic and foreign firms is important, especially in developing countries.

Of the various determinants of asset growth, factors related to the lagged asset size of the firm are the most widely discussed. Gibrat's law, ${ }^{2}$ also known as the law of

\footnotetext{
${ }^{1} \mathrm{Li}$ and Moshirian (2004); Yao et al. (2007); Ye et al. (2009).

2 Gibrat (1931).
} 
proportionate effects (LPE), suggests that the growth rates of firms are independent of their size. Previous studies using various industrial samples such as high-technology, manufacturing and retail firms offer mixed empirical results related to the LPE. ${ }^{3}$ Although these previous studies provide interesting findings regarding Gibrat's law, most empirical investigations have excluded highly regulated industries, such as finance and insurance. Yet asset growth could differ across industries, so investigating the specific determinants of asset growth in highly regulated industries may be an important issue for managing financial institutions.

Prior tests of Gibrat's law in the financial industry have focused on banking. ${ }^{4}$ Limited research examines Gibrat's law in the insurance area. For example, Hardwick and Adams ${ }^{5}$ investigate the relationship between firm size and firm growth in the U.K. life insurance industry during 1987-1996 and generally find support for Gibrat's law in the long term, though small life insurers achieved greater growth than large ones in this booming economic period. Choi ${ }^{6}$ tests Gibrat's law for U.S. property-liability insurance firms using data from 1992-2000 and offers strong support for it. Beyond asset size, factors such as age, profitability, expense ratios, product diversification and marketing strategy should be important determinants of a life insurer's growth. Hardwick and Adams and $\mathrm{Choi}^{5,6}$ both consider these factors to estimate growth rates.

To expand these interesting findings that relate asset growth across insurers, we propose studying the determinants of firm growth for life insurers in Taiwan. Compared with Hardwick and Adams and Choi, ${ }^{5,6}$ our study is motivated in two further respects. First, these authors use samples from, respectively, the United Kingdom and the United States, but the relationship between firm size and other characteristics could vary in different countries, especially for areas with distinct economic settings. Therefore, we study the determinants of firm growth for life insurers in a developing insurance market. Developing countries ${ }^{7}$ have attracted increasing numbers of foreign enterprises due to their rapid economic growth rate. In addition, previous studies show that the insurance industry differs notably between developed and developing countries. ${ }^{8}$ The number of insurers in developing countries is significantly less than in developed countries, ${ }^{9}$ and their organisational forms vary notably. In European countries and the

\footnotetext{
${ }^{3}$ Some studies have supported Gibrat's law (Geroski and Machin (1993); Goddard et al. (2002); Geroski et al. (2003)), whereas others reject it (Hall (1987); Hamilton et al. (2002); Audretsch et al. (2004); Mueller (2008)). Thus, confirmation varies across industries, countries and time periods, with no consensus opinion.

${ }^{4}$ Alhadeff and Alhadeff (1964); Rhoades and Yeats (1974); Yeats et al. (1975); Tschoegl (1983); Goddard et al. (2004).

${ }^{5}$ Hardwick and Adams (2002).

${ }^{6}$ Choi (2010).

${ }^{7}$ A developed country is one with a high level of development, according to criteria such as gross domestic product (GDP) and the human development index (HDI). The United Nation cites Japan in Asia, Canada and the United States in North America, Australia and New Zealand in Oceania, and most European countries as developed countries. During our sample period, we regard Asian countries except for Japan as developing countries (source: United Nations Development Programme).

${ }^{8}$ Chen et al. (1999); Chen and Wong (2004).

${ }^{9}$ The number of life insurers per country is as follows: China 59 (local firms 31; foreign firms 28); Malaysia 40 (local firms 34; foreign firms 6), Japan 43 (local firms 24; foreign firms 19), and South Korea 23 (local firms 13; foreign firms 10).
} 
United States, mutual-form life insurers earn half the premium income of the entire insurance market, but the organisational forms of most insurers in developing countries are stock companies. Therefore, insurers in developing countries may exhibit different asset growth patterns related to their specific characteristics, compared with insurers in developed countries. If an empirical work contains only data from developed countries, it may neglect specific characteristics of the insurance industry in developing countries.

Second, to the best of our knowledge, no paper attempts to explain whether or why domestic and foreign life insurers might have different determinants of growth. In the past decade, the insurance market in developing countries has grown rapidly. Owing to the booming economies in Asian countries, the insurance demand has been elicited and attracted the entry of many foreign insurers. As a result, foreign life insurance firms now constitute a substantial portion of the life insurance industry in Asia. Some features of the insurance profession, such as actuarial pricing, reserving and assetliability management (ALM), likely reflect the greater expertise of foreign life insurance firms, compared with domestic firms in developing countries. The insurance operations experience in developed countries provides an excellent example for the governments in developing countries. Thus, the governments in developing countries have little alternative but to follow developed countries' paths in the initial period of building their insurance industry. Even if foreign insurers do not have the largest market share in the local insurance market, they still possess advanced experience, innovative product design and new market strategies for developing countries. Thus, whether the asset growth determinants differ for foreign life insurers compared with domestic life insurers is an important question to be addressed.

To investigate these determinants for foreign and domestic life insurers, we consider the Taiwan life insurance industry, which is more sound and less regulated than the industry in many other developing countries. We use Heckman's two-stage regression to find the determinants of firm growth. In this regression model, beyond asset and country factors, we consider firm-specific factors that describe the operations of insurance companies in Taiwan such as age, product diversification, expense ratio, cross-marketing and profitability. By using the data for the Taiwan insurance market during 1996-2007, we find empirically that Gibrat's law may not hold, regardless of whether we consider domestic or foreign firms. Smaller life insurers achieve greater growth than large insurers. During the sample period, Taiwan's insurance industry was growing quickly, and our findings reinforce Hardwick and Adams's ${ }^{5}$ argument that Gibrat's law tends to fail during high-growth periods. The greater profitability and lower expense ratios also stimulate asset growth for life insurers. Moreover, we find that different factors affect the growth of domestic and foreign life insurers in Taiwan. Smaller, younger and more profitable domestic insurance firms enjoy higher growth rates. In contrast, smaller and older foreign life insurers attain higher growth rates than larger, younger ones. Cross-marketing and a concentrated product strategy encourage the foreign life insurer's growth rate.

We organise the remainder of this article as follows: In the next section, we introduce Taiwan's life insurance industry, before presenting the model settings, including the variables, hypotheses and regression models in the subsequent section. The description of the data and empirical evidence appear in the penultimate section. Finally, we offer some conclusions and suggestions of potential areas of interest for further research in this field. 
The Geneva Papers on Risk and Insurance-Issues and Practice

Table 1 Total domestic and foreign insurers in Taiwan

\begin{tabular}{lrrrrrrrrrrr}
\hline & 1997 & 1998 & 1999 & 2000 & 2001 & 2002 & 2003 & 2004 & 2005 & 2006 & 2007 \\
\hline Domestic & 16 & 16 & 16 & 16 & 18 & 20 & 21 & 21 & 21 & 22 & 22 \\
Foreign & 15 & 17 & 18 & 16 & 12 & 10 & 8 & 8 & 9 & 8 & 9 \\
Total $_{\text {Total assets }}^{\mathrm{a}}$ & 1,581 & 1,857 & 2,171 & 2,531 & 2,831 & 3,498 & 4,576 & 5,450 & 6,485 & 7,736 & 8,712 \\
\hline
\end{tabular}

${ }^{\mathrm{a}}$ Measured by billions of NT dollars.

Data source: Taiwan Insurance Institution (TII).

\section{The background of Taiwan life insurance industry}

In 2009, the population in Taiwan was 23.17 million. According to International Monetary Fund statistics, the per capita GDP was US\$18,458. According to Zurich Swiss Reinsurance Company statistics, Taiwan's insurance penetration (i.e. ratio of insurance premiums to GDP) ranked first in the world in 2009, at 17.29 per cent (which consisted of life insurance at 14.19 per cent and P\&L insurance at 3.10 per cent). Compared with the U.K. (12.92 per cent) and U.S. (8.07 per cent) rates, Taiwan's insurance penetration is relatively high. Furthermore, its insurance density (i.e. average insurance expenditures per capita) reached US\$2,628 (life insurance US\$2,166 and P\&L insurance US\$462). Although Taiwan's life insurance market is still a developing insurance market, it is worth investigating the determinants of firm growth in this market and comparing it with the insurance markets of developed countries.

In the early 1960s, there were only seven ${ }^{10}$ life insurance companies in Taiwan. Before the 1980s, the market was conventional and closed, and then around 1987, new foreign life insurers ${ }^{11}$ started to enter as the government gradually opened the market to them. ${ }^{12}$ Thus, in the 1990s, the insurance industry in Taiwan started to develop and become more sound. The number of insurance firms increased from seven to more than 28 (see Table 1). These foreign life insurers introduced new concepts related to actuarial pricing knowledge, product design and marketing strategy, which exerted significant influences on the development of Taiwan's insurance market. Total assets expanded greatly, from NT\$1,328 billion in 1996 to NT\$8,712 billion in 2007 (see Figure 1). Our sample period, from 1996 to 2007, covers this period of expansion and entry of foreign life insurers, leading to Taiwan's well-developed, fastgrowing insurance market. Insurance market data from Taiwan thus are appropriate

${ }^{10}$ Cathay Life Insurance Co., Taiwan Life insurance Co., Nan Shan Life Insurance Co., Shin Kong Insurance Co., China Life Insurance Co., Kuo Hua Life Insurance Co. and First Life Insurance Co.

${ }^{11}$ The entering foreign insurance companies included New York Life Insurance Co., ING Co. and American Life Insurance Co.

${ }^{12}$ In 1987, Taiwan's insurance market opened to the United States. This developmental trend was consolidated in 1994, when all remaining global insurance corporations were offered the opportunity to establish branch offices and conduct business in Taiwan. 


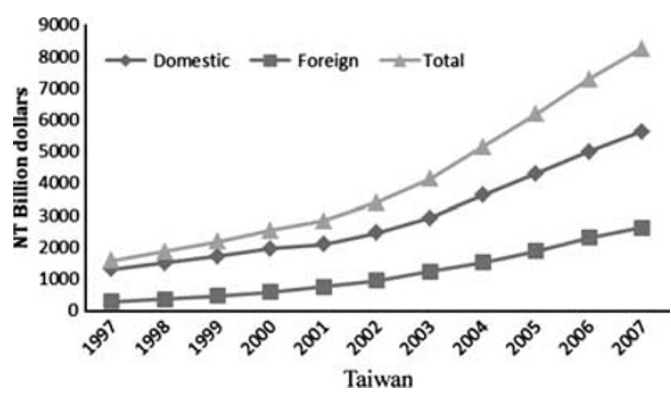

Figure 1. Asset values for domestic and foreign life insurers in Taiwan.

Note: Measured in billions of NT dollars.

for examining the determinants of growth for domestic and foreign life insurers in developing countries.

\section{Empirical model for firm growth}

\section{Variables}

In our regression model, the dependent variable is firm size. The independent variables include firm size in the previous and current year, as well as firm age (AGE), profitability (PR), expense ratio (ER) and product diversification (PD). ${ }^{13}$ We also include two dummy variables, cross-marketing (CM) and country (Coun), as we describe in detail in the following sections.

\section{Asset size}

We use the total assets of life insurance companies as a proxy for the size of a firm. The annual financial statement serves as a reliable indicator of the amount of assets held. A basic tenet of Gibrat's ${ }^{2}$ work is that asset-based growth is not correlated with firm size. Gibrat ${ }^{2}$ applied a stochastic model to test the French manufacturing sector and demonstrated that all firms, regardless of their size, have equal probabilities of proportionate growth. Many previous empirical studies have investigated whether corporate growth rates are independent of firm size, as Gibrat's law predicts. ${ }^{14}$ The stochastic process of growth according to firm size can be expressed as:

$$
S I Z E_{i, t} / S I Z E_{i, t-1}=\alpha \cdot S I Z E_{i, t-1}^{\beta_{1}-1} \varepsilon_{i, t},
$$

\footnotetext{
${ }^{13}$ Dunne and Hughes (1994) and Weiss (1998) examine various characteristics of firms, including capital costs, profitability and other factors with a bearing on growth rates.

${ }^{14}$ Evans (1987a); Hall (1987); Harhoff et al. (1998); Weiss (1998); Hardwick and Adams (2002); Calvo (2006); Choi (2010).
} 
where $S I Z E_{i, t}$ and $S I Z E_{i, t-1}$ represent, respectively, the size of firm $i$ in the current $(t)$ and previous $(t-1)$ periods; $\varepsilon_{i, t}$ is a disturbance term with the mean equal to 1 and constant variance; and $\alpha$ is the constant market rate of growth. From this equation, if $\beta_{1}$ equals 1 , firm growth is independent of initial size. That is, Gibrat's law holds. If $\beta_{1}$ is greater than 1, large firms grow faster than their small counterparts. If $\beta_{1}$ is less than 1 , the converse is true. Thus, Gibrat's law can be verified only if $\beta_{1}$ is not significantly different from 1. A typical size distribution is often assumed to be lognormal, ${ }^{15}$ which implies the following equation:

$$
\ln (\text { Size })_{i, t}=\beta_{0}+\beta_{1} \ln (\text { Size })_{i, t-1}+\mu_{i, t}
$$

where $\beta_{0}=\ln \alpha, \mu_{i, t}=\ln \varepsilon_{i, t}$ and $\ln \varepsilon_{i, t} \sim N\left(0, \sigma_{t}^{2}\right)$. In this case, $\beta_{1}$ should be positive, because the size of life insurers increases at an exponential rate. If $\beta_{1}$ is not significantly different from 1, we would confirm Gibrat's law. However, estimating Eq. (2) using ordinary least square (OLS) may generate possible econometric problems. First, the disturbance term may raise heteroscedasticity problems, because the variance of growth rates might not equal the various sizes of life insurance firms. If heteroscedasticity exists in the model, we could avoid such problems by using the heteroscedastic-consistent estimator provided by White. ${ }^{16}$ Second, Chesher ${ }^{17}$ warns that the beta estimation will be inconsistent if serial correlation exists in the growth persistence. Third, it is very important to deal with sample attrition. Heckman ${ }^{18}$ finds that the bias from using nonrandom selected samples generates specification errors in the regression. He provides a two-stage estimation to deal with this kind of problem; in a first equation, the binary variable for surviving firms represents the dependent variable in the regression. Then, the inverse Mill's ratio ${ }^{19}$ can be estimated in the second stage. We use Heckman's twostage regression to adjust to possible problems from sample attrition; all the relevant econometric problems will be tested in subsequent sections.

Age

The age of a life insurance firm might affect its growth. To investigate the relationship between firm age and firm growth, we define the independent variable, age, as the difference between the year the life insurer was founded and the sample year. Many articles have investigated whether young firms grow faster than old firms. Jovanovic ${ }^{20}$

\footnotetext{
${ }^{15}$ Dunne and Hughes (1994); Weiss (1998); Hardwick and Adams (2002); Calvo (2006); Choi (2010).

${ }^{16}$ White (1980).

${ }^{17}$ Chesher (1979).

${ }^{18}$ Heckman (1979).

${ }^{19}$ The inverse Mill's ratio is defined as the ratio of the probability density function to the cumulative distribution function. Heckman (1979) proposed the two-stage estimation procedure adopting the inverse Mill's ratio to deal with the selection bias problem. In the first step, the inverse Mill's ratio can be generated from the estimation of a probit model. The estimated parameters can be used to calculate the inverse Mills ratio, which is then included as an additional independent variable in the second regression.

${ }^{20}$ Jovanovic (1982).
} 
proposes a theoretical model to predict that surviving younger firms grow faster than older firms. Furthermore, many studies have used empirical data to test whether an inverse relationship exists between firm age and firm growth; most of them support this conclusion. ${ }^{21}$ Yasuda ${ }^{22}$ shows that firm size and age have negative effects on firm growth among a sample of Japanese manufacturing firms. Calvo ${ }^{23}$ finds that small, young firms have higher growth rates than large and old ones, according to a sample of 1,272 Spanish firms. Among 823 property-liability insurance firms in the United States, $\mathrm{Choi}^{6}$ finds that young firms grow faster than old firms. However, the few empirical results that indicate a negative impact of firm age on corporate growth have not been confirmed. ${ }^{24,5}$ For example, Audretsch et al. ${ }^{24}$ find no relationship between firm age and growth among retail and hospitality industry firms in the Netherlands. Hardwick and Adams ${ }^{5}$ document that age cannot explain firm growth by U.K. life insurance firms. Overall, we anticipate a negative relationship between firm age and firm growth.

\section{Profitability $(P R)$}

The total operating income of insurance companies consists of two components: financial and underwriting income. Profitability reflects the monetary difference between total income and total expenditures (i.e. value of losses and relevant expenses). Profit margins are unquestionably an important source of firm growth in various industries, but the relationship between profitability and asset growth remains somewhat obscure. A positive relationship marks firm growth and profitability, in that higher profit can help firms obtain more financing from retained profit. Some articles have supported the view that current profit provides a guarantor of future asset growth. ${ }^{25}$ Geroski et al. ${ }^{26}$ note a positive relationship between profitability and firm growth over the long term in their U.K. study. Elango et al. $^{27}$ find a positive association between risk-adjusted returns on equity and asset size in the U.S. property-liability insurance industry. In contrast, other studies discover negative relationships between firm growth and profitability. ${ }^{28}$ This negative relationship may arise because managers cut prices and make aggressive moves to exchange current profits for future asset growth. Moreover, Santomero and Babbel ${ }^{29}$ observe that the unpredictable nature of economic shocks has an adverse effect on the profitability and product development of life insurers. Their empirical results suggest that life insurer's growth rates are likely to be unpredictable if future economic shocks also are largely unpredictable. Finally, some studies find no significant relationship between profitability and firm growth. ${ }^{5,6}$ Using the ratio of net profit to total net written premiums as proxies for profitability, we predict that the relationship between probability and

${ }^{21}$ Dunne and Hughes (1994); Yasuda (2005); Calvo (2006); Choi (2010).

${ }^{22}$ Yasuda (2005).

${ }^{23}$ Calvo (2006).

${ }^{24}$ Audretsch et al. (1997).

${ }^{25}$ Sommer (1996); Geroski et al. (1997); Cummins and Nini (2002); Elango et al. (2008).

${ }^{26}$ Geroski et al. (1997).

${ }^{27}$ Elango et al. (2008).

${ }^{28}$ Whittington (1980); Lai and Limpaphayom (2003).

${ }^{29}$ Santomero and Babbel (1997). 
growth might be either positive or negative; we also consider current and lagged values of profitability.

Expense ratio (ER)

The expenditure components of the life insurance industry differ from those of other industries. Typical expenditures in the income statements of life insurers include insurance claims, preparing reserves and operational expenses. However, the first two items have no direct bearing on operational costs. We adopt Ambrose and Seward's ${ }^{30}$ definition and use the following equation to proxy for the ER:

$$
E R=(A E+A D E) / T P,
$$

where $A E$ denotes the acquisition expense, $A D E$ is administrative expenses and $T P$ represents the total written premium. The net commission, allowance for management and agents, and salaries are included in expenses. A higher ER could mean that cost inefficiency relates to disproportionate economies of scale or a misallocation of resources. Many studies support the notion that more efficient insurers use less inputs. ${ }^{31}$ Insurers with lower expense ratios achieve more efficient resource allocations than their competitors and thus should enjoy a higher asset growth rate. Furthermore, higher current expense ratios could impede asset growth. ${ }^{5,6}$ Therefore, we predict that, other things being equal, life insurance companies in Taiwan with higher ER grow at a slower rate than their competitors with lower ER. We again use current and lagged values of these expense ratios.

\section{Product diversification (PD)}

Life insurers have complex product lines, including life insurance, health insurance, annuity, accident and investment-linked products. Cash outflow patterns vary with the different insurance products. Larger firms may have more resources to proceed with product diversification to enhance their sales. However, such opportunities may be squandered in situations in which over-diversification exerts a corrosive effect on firm growth. The Herfindahl-Hirschman index (HHI) traditionally has served as a measure of firm size in relation to the industry, as well as an indicator of the amount of competition in one industry. Mayers and Smith ${ }^{32}$ used the HHI as a proxy for insurers' product diversification. For each life insurance company, the HHI can be calculated as follows:

$$
P D=\sum_{L=1}^{n} S_{L}^{2} \text { and } S_{L}=P I_{L} / T P I
$$

\footnotetext{
${ }^{30}$ Ambrose and Seward (1988).

${ }^{31}$ For example, Berger et al. (1997); Cummins et al. (1999); Hardwick and Adams (2002); Choi and Weiss (2005); Choi (2010).

32 Mayers and Smith (1988).
} 
where $P D$ indicates product diversification, $S_{L}$ is the weight of different businesses, $L$ is the line of business, $P I_{L}$ is the dollar amount of direct business written in a particular line of insurance and TPI is the aggregate dollar amount of direct business across all lines of insurance. A lower HHI indicates more diversified insurers; a higher value indicates more specialised insurers. If economic scope exists in the insurance industry, it will show that more diversified firms grow quickly.

Prior studies instead offer mixed results regarding the benefits of product diversification. Insurers managing more lines of business grow faster than those specialising in fewer lines. ${ }^{5,6}$ However, some studies support the diversification discount hypothesis: According to BarNiv and Hershbarger, ${ }^{33}$ alteration of the product mix affects smaller life insurers adversely, and Berger and Ofek $^{34}$ argue that managers of highly diversified firms could find it difficult to deal with increasingly dissimilar business operations. Furthermore, Elango et al..$^{27}$ show that the extent of product diversification has a complex, nonlinear relationship with performance. Applying these insights to Taiwan's life insurance industry, we expect the negative relationship between asset growth and product diversification because the life insurers with more diversified product lines enjoy higher growth rates if they possess sufficient economic scope.

\section{Cross-marketing (CM)}

Article 13 of the Insurance Act of the Republic of China stipulates that one insurance company cannot simultaneously offer life and non-life insurance products in Taiwan. However, in 2003, the Taiwanese government encouraged greater autonomy of the financial industry and allowed institutional reform. Life insurance companies belonging to affiliated and non-affiliated financial groups could exhibit different behaviour in terms of their insurance operations and market strategies. Some life insurers that belong to the certain affiliated financial groups in Taiwan, such as Cathay, Shin Kong and Fubon, sell life products in group banking systems, which affords them considerable scope for promoting their business. This strategy extends to cross-marketing, such that one life insurer can use the resources of other group members to promote its business. Webster ${ }^{35}$ details several advantages of such cross-marketing in groups that entail longterm relationships, buyer and seller partnerships, network organisations and vertical integration. Membership in the same financial group constitutes a form of long-term relationship in Taiwan. Furthermore, life insurance companies can access the consumer lists of other companies in the same group, for their own benefit. We deploy crossmarketing as a dummy variable and test whether a life insurance company in an affiliated financial group reaps tangible benefits from cross-marketing. The dummy variable equals 1 if the life insurer belongs to an affiliated financial group (and 0 otherwise). $\mathrm{Choi}^{6}$ supports the prediction that an insurer in a group tends to grow faster in the U.S. property-liability insurance industry. However, Hardwick and Adams ${ }^{5}$ imply the pure life insurers enjoy higher growth rates. They explain this perplexing finding by suggesting the possibility of diseconomies of scope. Although this issue clearly is worthy

\footnotetext{
33 BarNiv and Hershbarger (1990).

${ }^{34}$ Berger and Ofek (1995).

${ }^{35}$ Webster (1992).
} 
of further investigation, we still predict a positive relationship between asset growth and cross-marketing.

\section{Country (Coun)}

Foreign insurers often play important roles in developing countries. Many enter developing country markets to gain access to their growing economies. Insurance expertise, such as ALM technologies, is stronger among foreign than among local insurers in developing countries. But local companies often can more successfully exploit familiarity with management styles and cultural background issues compared with their foreign rivals. We therefore use the life insurance companies' country as a dummy variable to test company performance, such that a domestic life insurer equals 1 (foreign=0). Yao et al. ${ }^{36}$ use the panel data over the period 1999-2004 in China and find that there is no evidence to support that foreign insurers tend to be more efficient than domestic ones. Furthermore, Chen et al. ${ }^{37}$ use data obtained from the life insurance industry in China during the period from 2002 to 2008 and indicate that the foreign insurers have relatively lower efficiency. $\mathrm{Hao}^{38}$ also finds that domestic life insurers have better overall performance than foreign peers in Taiwan. Thus, we predict that domestic life insurance companies grow faster than foreign ones. We summarise the definitions and hypotheses for each variable in Table 2.

\section{Model specification}

Our empirical model expands Eq. (2) by adding other firm-specific factors that might influence asset growth. Many previous studies use firm-specific characteristics to test growth determinants. ${ }^{39}$ Using variables from prior research, we consider relevant firmspecific characteristics for the Taiwan life insurance industry. In addition, we attempt to address econometric concerns, such as heteroscedasticity, serial correlation bias, multicollinearity and sample attrition. We use the two-stage regression method to test the determinants of life insurers' growth in Taiwan, which we define as:

$$
\begin{aligned}
\ln (S I Z E)_{i, t}= & \beta_{0}+\beta_{1} \ln (S I Z E)_{i, t-1}+\beta_{2}(\text { Age })_{i, t}+\beta_{3}(P R)_{i, t} \\
& +\beta_{4}(P R)_{i, t-1}+\beta_{5}(E R)_{i, t}+\beta_{6}(E R)_{i, t-1}+\beta_{7}(P D)_{i, t} \\
& +\beta_{8}(C M)_{i, t}+\beta_{9}(\text { Coun })_{i, t}+\varepsilon_{i, t},
\end{aligned}
$$

where the subscripts $t$ and $t-1$ indicate the current and prior year, respectively. We measure the asset size of firm $i$ at time $t$ after taking the natural logarithms of the dependent variable. That is, the natural logarithm of the asset size of firm $i$ at time $t$ provides the independent variable to test Gibrat's law. If Gibrat's law holds,

\footnotetext{
${ }^{36}$ Yao et al. (2007).

${ }^{37}$ Chen et al. (2009).

${ }^{38}$ Hao (2009).

${ }^{39}$ Dunne and Hughes (1994); Weiss (1998); Hardwick and Adams (2002); Goddard et al. (2004); Yasuda (2005); Choi (2010).
} 
Table 2 Variable definitions, expected results and hypotheses

\begin{tabular}{|c|c|c|}
\hline Variable names & Variable definitions & Expect results \\
\hline $\begin{array}{l}\text { Corporate asset } \\
\text { size }\end{array}$ & $\begin{array}{l}(S I Z E)_{i, t} \text { and }(S I Z E)_{i, t-1} \text { are the size of firm } i \text { at time } t \text { (this period) and } \\
\text { time } t-1 \text { (previous period), respectively. }\end{array}$ & + \\
\hline Age & $\begin{array}{l}A g e_{i} \text { is the difference between the founding year of the life insurance } \\
\text { company and the sample year. }\end{array}$ & - \\
\hline Profitability & $\begin{array}{l}P R_{i, t} \text { is the profitability of firm } i \text { at time } t \text {, defined as the ratio of net } \\
\text { profit to total net written premium. }\end{array}$ & - or + \\
\hline Expense ratio & $\begin{array}{l}E R_{i, t} \text { is the expense ratio of firm } i \text { at time } t \text {, defined as the acquisition } \\
\text { expenses plus administrative expenses divided by total written } \\
\text { premiums (see Eq. 3). }\end{array}$ & - \\
\hline $\begin{array}{l}\text { Product } \\
\text { diversification }\end{array}$ & $\begin{array}{l}P D_{i, t} \text { is the product diversification of firm } i \text { at time } t \text {, as defined in } \\
\text { Eq. (4) and measured by HHI. }\end{array}$ & - \\
\hline Cross-marketing & $\begin{array}{l}C M_{i, t} \text { is the cross-marketing dummy variable of firm } i \text { at time } t . \text { Life } \\
\text { insurer with affiliated financial group }=1 \text {; life insurer without affiliated } \\
\text { financial group }=0 .\end{array}$ & + \\
\hline Country & $\begin{array}{l}\text { Coun }_{i, t} \text { is the country dummy variable of firm } i \text { at time } t \text {. Domestic life } \\
\text { insurer }=1 \text {; foreign branch life insurer }=0 .\end{array}$ & + \\
\hline \multicolumn{3}{|l|}{ Hypotheses } \\
\hline \multicolumn{3}{|c|}{$\begin{array}{l}\text { - H2: Other things being equal, younger life insurance companies have higher growth rates than older life } \\
\text { insurance companies. }\end{array}$} \\
\hline \multirow{2}{*}{\multicolumn{3}{|c|}{$\begin{array}{l}\text { - H3: Other things being equal, life insurance companies in Taiwan should show either a positive or } \\
\text { negative relationship between firm growth and profitability. } \\
\text { - H4: Other things being equal, life insurance companies with higher expense ratios in Taiwan will grow } \\
\text { more slowly. }\end{array}$}} \\
\hline & & \\
\hline \multirow{2}{*}{\multicolumn{3}{|c|}{$\begin{array}{l}\text { - H5: Other things being equal, life insurance companies with more diversified products have higher } \\
\text { growth rates than those with more specialised products in Taiwan. } \\
\text { - H6: Other things being equal, life insurance companies affiliated to a financial group have higher growth } \\
\text { rates than others in Taiwan. }\end{array}$}} \\
\hline & & \\
\hline \multicolumn{3}{|c|}{$\begin{array}{l}\text { - H7: Other things being equal, domestic life insurance companies grow faster than foreign branch life } \\
\text { insurance companies. }\end{array}$} \\
\hline
\end{tabular}

$\beta_{1}$ should not differ significantly from 1 . If $\beta_{1}$ is significantly less (greater) than 1 , it means that small (large) firms grow faster than large (small) firms. As a robustness check, we follow the methodology provided by Goddard et $a l .{ }^{40}$ to study two growth effects: static and dynamic. In the static growth model, we use the average natural logarithm asset size of firm $i$ during the specific period ${ }^{41}$ as the independent variable; in dynamic growth model, we use the natural logarithm asset size of firm $i$ in year $t$ as independent variable. We also consider age $(A g e)$, current probability $(P R)_{t}$, lagged profitability $(P R)_{t-1}$, current expense ratio $(E R)_{t}$, lagged expense ratio $(E R)_{t-1}$ and product diversification $(P D)$ as independent variables. The two dummy variables, cross-marketing and country, are represented by $C M$ and Coun, respectively. To

\footnotetext{
${ }^{40}$ Goddard et al. (2004).

${ }^{41}$ We divided the whole sample period (1996-2007) into two sub-periods (1996-2001 and 2002-2007). We calculate the average natural logarithm asset size of firm $i$ during two sub-periods (1996-2001 and 2002-2007) and whole sample period (1996-2007) as the independent variable.
} 
Table 3 Summary statistics

\begin{tabular}{|c|c|c|c|c|c|}
\hline \multirow[t]{2}{*}{ Variables } & \multicolumn{2}{|c|}{ Surviving firms } & \multicolumn{3}{|c|}{ Non-surviving firms } \\
\hline & Mean & Std. deviation & Mean & Std. deviation & $t$-test \\
\hline Lag log size & $\$ 170.78$ & $\$ 355.05$ & $\$ 23.63$ & $\$ 33.69$ & $* * *$ \\
\hline Age & 19.9269 & 14.5578 & 21.8537 & 24.1512 & \\
\hline Profitability (current) & -0.0271 & 0.0871 & -0.0583 & 0.1075 & $* *$ \\
\hline Profitability (lagged) & -0.0418 & 0.1182 & -0.0861 & 0.1363 & $* *$ \\
\hline Expense ratio (current) & 0.3269 & 0.2542 & 0.4669 & 0.3587 & $* *$ \\
\hline Expense ratio (lagged) & 0.3795 & 0.3492 & 0.8681 & 2.0947 & $* *$ \\
\hline Product diversification & 0.6403 & 0.1300 & 0.7075 & 0.1941 & $* *$ \\
\hline Cross-marketing & 0.2000 & 0.4008 & 0.1707 & 0.3809 & \\
\hline Country & 0.5385 & 0.4995 & 0.2683 & 0.4486 & $* * *$ \\
\hline Observations & \multicolumn{2}{|c|}{260} & \multicolumn{2}{|c|}{41} & \\
\hline
\end{tabular}

Note: Values are in billions of NT dollars.

***,** Significant at 1 per cent and 5 per cent level respectively.

determine whether different factors affect the asset growth of life insurers in Taiwan, we divided the entire sample into domestic vs foreign life insurers. As a robustness check of the effects of different market conditions, we also divided the study period (1996-2007) into two sub-periods (1996-2001 and 2002-2007).

\section{Empirical results}

\section{Data resources and summary statistics}

We collect data for the 1996-2007 study period from the Taiwan Life Insurance Association and Taiwan Insurance Institute (TII). The total sample consists of 301 firm-year observations, including both surviving and non-surviving life insurance firms. During the sample period, the average GDP growth rate in Taiwan reached 4.63 per cent, and the annual GDP growth rate was positive for all years except during the Internet bubble in 2001. Considering its previously closed status and gradual expansion as the government opened the market, the insurance industry in Taiwan represents a young, fast-growing insurance market.

Table 3 offers summary statistics for surviving and non-surviving firms ${ }^{42}$ and $t$-test results. A surviving firm must exist for the entire sample period (1996-2007). We note significant differences across most variables, especially firm size and country, between surviving and non-surviving firms at the 1 per cent level. The mean of total assets for surviving firms is approximately NT\$170 billion, significantly larger than that for non-surviving firms (NT\$23.63 billion). No significant differences arise for firm age between surviving and non-surviving firms. The profitability of surviving firms is higher and more stable than that of non-surviving firms, such that the average

\footnotetext{
${ }^{42}$ We exclude four missing data points. Thus, the total sample of surviving firms is 260 .
} 
profitability is higher, but the standard deviation of that profitability is lower. That is, life insurers with more and more stable profits are more likely to survive. Similarly, surviving firms exhibit lower expense ratios than non-surviving firms. Firms enjoy a higher probability of surviving if they are cost efficient. The PD variable further indicates that the product strategies of surviving firms tend to be more diversified than those for non-surviving firms. Surviving firms also are more likely to be affiliated with a financial group (20 per cent) than non-surviving firms (17.07 per cent). On average, about 53 per cent of surviving firms are domestic, but only 27 per cent of non-surviving firms are. That is, the non-surviving life insurers that withdraw from Taiwan are mostly foreign life insurers. Accordingly, we note that life insurers that are larger, are more profitable, have lower expense ratios, exhibit more product diversification and use cross-marketing are more likely to survive in the Taiwanese insurance market.

In the following, we only consider the surviving firms for our analysis. Table 4 lists the means and standard deviations for domestic and foreign life insurers for the entire sample period (1996-2007) and the two sub-periods (1996-2001, 2002-2007). The two sub-periods represent different market conditions in Taiwan's insurance market: During the former, interest rates were high, whereas the latter was marked by a low interest rate environment. The average asset size of the domestic life insurers increased from nearly NT\$138 billion in 1996-2001 to NT\$307 billion in 2002-2007. We also find asset expansion for foreign life insurers (from NT\$43 billion to NT\$159.5 billion). The average asset size of domestic life insurers (NT\$226.2 billion) was significantly larger than that of foreign life insurers (NT\$106.3 billion). Moreover, the average age of the domestic life insurers (24.9 years) was significantly greater than that of foreign life insurers (20.567 years). The average profitability ratio of domestic life insurers increased, from negative 5.6 per cent in 1996-2001 to 0.04 per cent (nearly breaking even) in 2002-2007 (significant at 1 per cent level, see Table 4). Although foreign life insurers still earned lower profits than domestic life insurers, they improved their profitability ratio, such that the average expense ratios of domestic (foreign) life insurers shifted from nearly $0.3706(0.5093)$ to $0.1896(0.2899)$ by the latter sub-period (significant at 1 per cent level, see Table 4). Domestic life insurers also achieved better cost efficiency than foreign life insurers. The reason could be attributed to foreign life insurers having more expenditure on establishing branches and recruiting new employees than domestic life insurers in the beginning of entering the new market. According to the HHI, domestic life insurers engaged in less diversified production $(\mathrm{HHI}=0.68)$ than foreign life insurers $(\mathrm{HHI}=0.58)$. However, foreign insurers appear to have concentrated gradually on specialised products (product diversification increased from 0.58 in 1996-2001 to 0.67 in 2002-2007). For domestic life insurers, the significant difference between product diversification in 1996-2001 (0.68) and in 2002-2007 (0.62) implies that domestic life insurers intend to take more diversified product strategy. This phenomenon could reflect the development of investment-linked insurance products, first introduced in Taiwan by the foreign life insurer Manulife in 2000. Unlike traditional life insurance holders, policyholders who purchase investmentlinked insurance bear investment risk. To reduce the pressures of interest rate risk for traditional life insurance in low interest rate environments, the issuance of investment-linked insurance products is becoming more popular in Taiwan's insurance 
Table 4 Summary statistics over time and country

\begin{tabular}{|c|c|c|c|c|c|c|c|c|c|c|c|}
\hline \multirow[t]{2}{*}{ Variable } & \multicolumn{3}{|c|}{$1996-2001$} & \multicolumn{3}{|c|}{$2002-2007$} & \multicolumn{3}{|c|}{ 1996-2007 } & \multicolumn{2}{|c|}{$\begin{array}{l}t \text {-test for the difference across periods } \\
1996-2001 \text { vs 2002-2007 }\end{array}$} \\
\hline & Domestic & Foreign & t-test & Domestic & Foreign & t-test & Domestic & Foreign & $t$-test & Domestic & Foreign \\
\hline Asset size & $\begin{array}{l}\$ 138.0 \\
(\$ 266)\end{array}$ & $\begin{array}{l}\$ 43.1 \\
\quad(\$ 102)\end{array}$ & $* * *$ & $\begin{array}{l}\$ 307.1 \\
\quad(\$ 508)\end{array}$ & $\begin{array}{l}\$ 159.5 \\
(\$ 302)\end{array}$ & $* *$ & $\begin{array}{l}\$ 226.2 \\
(\$ 423)\end{array}$ & $\begin{array}{l}\$ 106.3 \\
(\$ 239)\end{array}$ & $* * *$ & $* * *$ & $* * *$ \\
\hline Age & $\begin{array}{c}22.016 \\
(16.585)\end{array}$ & $\begin{array}{c}17.545 \\
(10.658)\end{array}$ & $*$ & $\begin{array}{c}27.421 \\
(16.673)\end{array}$ & $\begin{array}{c}23.123 \\
(10.749)\end{array}$ & $* * *$ & $\begin{array}{l}24.9 \\
(16.792)\end{array}$ & $\begin{array}{c}20.567 \\
(11.022)\end{array}$ & $*$ & & \\
\hline Profitability (lagged) & $\begin{array}{c}-0.0810 \\
(0.1210)\end{array}$ & $\begin{array}{r}-0.0920 \\
0.1991\end{array}$ & & $\begin{array}{c}-0.0030 \\
(0.0219)\end{array}$ & $\begin{array}{r}-0.0060 \\
(0.0361)\end{array}$ & & $\begin{array}{c}-0.039 \\
(0.0919)\end{array}$ & $\begin{array}{c}-0.046 \\
(0.1432)\end{array}$ & & $* * *$ & $* * *$ \\
\hline Expense ratio (current) & $\begin{array}{c}0.3706 \\
(0.2392)\end{array}$ & $\begin{array}{c}0.5093 \\
(0.3075)\end{array}$ & $* * *$ & $\begin{array}{c}0.1896 \\
(0.1722)\end{array}$ & $\begin{array}{c}0.2899 \\
(0.1908)\end{array}$ & $* * *$ & $\begin{array}{c}0.2723 \\
(0.2239)\end{array}$ & $\begin{array}{c}0.3905 \\
(0.273)\end{array}$ & $* * *$ & $* * *$ & $* * *$ \\
\hline Expense ratio (lagged) & $\begin{array}{c}0.4664 \\
(0.3192)\end{array}$ & $\begin{array}{c}0.6184 \\
(0.5171)\end{array}$ & $*$ & $\begin{array}{c}0.1943 \\
(0.1556)\end{array}$ & $\begin{array}{c}0.3085 \\
(0.1918)\end{array}$ & $* * *$ & $\begin{array}{c}0.3187 \\
(0.2788)\end{array}$ & $\begin{array}{c}0.4505 \\
(0.4064)\end{array}$ & $* * *$ & $* * *$ & $* * *$ \\
\hline Product diversification & $\begin{array}{c}0.6824 \\
(0.1045)\end{array}$ & $\begin{array}{c}0.5825 \\
(0.1095)\end{array}$ & $* * *$ & $\begin{array}{c}0.6224 \\
(0.1442)\end{array}$ & $\begin{array}{c}0.6662 \\
(0.1357)\end{array}$ & * & $\begin{array}{c}0.6509 \\
(0.1288)\end{array}$ & $\begin{array}{c}0.6278 \\
(0.1307)\end{array}$ & & $* * *$ & $* * *$ \\
\hline Cross-marketing & $\begin{array}{c}0.2969 \\
(0.4605)\end{array}$ & $\begin{array}{c}0.0909 \\
(0.2901)\end{array}$ & $* * *$ & $\begin{array}{c}0.2895 \\
(0.4565)\end{array}$ & $\begin{array}{c}0.0923 \\
(0.2917)\end{array}$ & $* * *$ & $\begin{array}{c}0.2929 \\
(0.4567)\end{array}$ & $\begin{array}{c}0.0917 \\
(0.2898)\end{array}$ & $* * *$ & & \\
\hline Observations & 64 & 55 & & 76 & 65 & & 140 & 120 & & & \\
\hline
\end{tabular}

Notes: This table shows the means and standard deviations (in brackets) of the variables included in the regression analysis. The amounts are measured in billions of NT dollars.

$* * *, * * *$ Significant at 1 per cent, 5 per cent and 10 per cent level respectively. 
industry. ${ }^{43}$ However, foreign and domestic life insurers have different product strategies. Foreign life insurers are keener to issue investment-linked products than are domestic life insurers, because the former have more experience designing and selling investmentlinked insurance products from overseas parent companies. Therefore, we find that the product diversification strategies for foreign and domestic life insurers changed across the different sub-periods. As a result, the effect of product diversification on asset growth could differ among local and foreign insurers. Domestic life insurers (29 per cent) use more cross-marketing channels than foreign life insurers $(9$ per cent). Furthermore, we also have used a $t$-test for the difference across periods in last two columns of Table 4 . The average profitability ratios of domestic and foreign life insurers in 2002-2007 are both significantly higher than these ratios in 1996-2001. Besides two variables, age and cross-marketing, the $t$-test statistics of other independent variables across two sub-periods differ significantly. According to Tables 3 and 4, we note that Taiwan is a young but fast growing insurance market. Regardless of whether domestic or foreign, the asset size and profitability of life insurers continuously increase during our sample period.

\section{Econometric testing and adjustment}

\section{Heteroscedasticity and multicollinearity}

Many previous studies have suggested that the firm size-growth equation could lead to disturbance heteroscedasticity. ${ }^{44}$ We use relevant tests, including the Lagrange multiplier test, the White test and the Breusch-Pagan test, to investigate the null hypothesis of homoscedasticity. The empirical testing results allow us to reject the null hypothesis of homoscedasticity for all sample periods at the 10 per cent level of significance. Thus, to follow Choi, ${ }^{6}$ we use the heteroscedastic-consistent estimators provided by White ${ }^{16}$ to deal with the problems associated with heteroscedasticity. We calculate Pearson correlations for all variables for the entire sample period in Table 5. We find a positive relationship among the asset size, lagged asset size, firm age, profitability, cross-market and country variables. However, the expense ratio always shows negative relationships with the other variables. Therefore, we predict that life insurers with greater profitability and less product diversification achieve higher asset growth. In contrast, life insurers with higher expense ratios reveal a slower pace of increasing asset size. The Pearson correlations for most variables are less than 0.5 in magnitude. Therefore, the probability that an inefficient estimator results from multicollinearity for the variables is very small. To be especially cautious about multicollinearity, we further examine its possibility by using variance inflation factors, none of which exceeded $3 .^{45}$ Thus, our empirical results confirm that problems associated with multicollinearity do not exist in our regression model.

\footnotetext{
${ }^{43}$ The total premium of investment-linked products increases from NT\$8.1 billion in 2002 to NT\$601.8 billion in 2007.

44 Jovanovic (1982); Dunne and Hughes (1994); Hardwick and Adams (2002); Choi (2010).

${ }^{45}$ Gujarati (1995) suggests variables may be highly collinear if the variable inflation factor exceeds 10 . Our test shows $\ln (\text { Size })_{t-1}$ 2.82; age 1.59; PR 1.27; ER 2.03; PD 1.18; CM 1.49; Coun 1.34.
} 
Table 5 Pearson correlations matrix (1996-2007)

\begin{tabular}{|c|c|c|c|c|c|c|c|c|c|c|}
\hline & $\begin{array}{l}\text { Asset } \\
\text { size }\end{array}$ & $\begin{array}{c}\text { Lag asset } \\
\text { size }\end{array}$ & Age & $\begin{array}{l}\text { Profitability } \\
\text { (current) }\end{array}$ & $\begin{array}{l}\text { Profitability } \\
\text { (lagged) }\end{array}$ & $\begin{array}{c}\text { Expense ratio } \\
\text { (current) }\end{array}$ & $\begin{array}{c}\text { Expense ratio } \\
\text { (lagged) }\end{array}$ & $\begin{array}{c}\text { Product } \\
\text { diversification }\end{array}$ & $\begin{array}{l}\text { Cross- } \\
\text { marketing }\end{array}$ & Country \\
\hline Asset size & 1 & 0.6698 & 0.4503 & 0.1908 & 0.2025 & -0.2675 & -0.1349 & -0.023 & 0.4949 & 0.1932 \\
\hline Lag asset size & 0.6698 & 1 & 0.5791 & 0.4609 & 0.5331 & -0.5798 & -0.3877 & 0.0944 & 0.4279 & 0.4157 \\
\hline Age & 0.4503 & 0.5791 & 1 & 0.2836 & 0.3307 & -0.3216 & -0.2033 & 0.1695 & 0.1570 & 0.2863 \\
\hline $\begin{array}{l}\text { Profitability } \\
\text { (current) }\end{array}$ & 0.1908 & 0.4609 & 0.2836 & 1 & 0.6347 & -0.5756 & -0.4586 & 0.0223 & 0.1375 & 0.0838 \\
\hline $\begin{array}{l}\text { Profitability } \\
\text { (lagged) }\end{array}$ & 0.2025 & 0.5331 & 0.3307 & 0.6347 & 1 & -0.5907 & -0.4507 & 0.0229 & 0.1396 & 0.1022 \\
\hline $\begin{array}{l}\text { Expense ratio } \\
\text { (current) }\end{array}$ & -0.2675 & -0.5798 & -0.321 & -0.5756 & -0.5907 & 1 & 0.6618 & -0.0406 & -0.2063 & -0.2951 \\
\hline $\begin{array}{l}\text { Expense ratio } \\
\text { (lagged) }\end{array}$ & -0.1349 & -0.3877 & -0.2033 & -0.4586 & -0.4507 & 0.6618 & 1 & -0.0487 & -0.0909 & -0.161 \\
\hline $\begin{array}{l}\text { Product } \\
\text { diversification }\end{array}$ & -0.0232 & 0.0944 & 0.1695 & 0.0223 & 0.0229 & -0.0406 & -0.0487 & 1 & -0.0864 & 0.1172 \\
\hline Cross-marketing & 0.4949 & 0.4279 & 0.1570 & 0.1375 & 0.1396 & -0.2063 & -0.0909 & -0.0864 & 1 & 0.1908 \\
\hline Country & 0.1932 & 0.4157 & 0.2863 & 0.0838 & 0.1023 & -0.2951 & -0.1618 & 0.1172 & 0.1908 & 1 \\
\hline
\end{tabular}


Serial correlation bias test

Chesher ${ }^{17}$ argues that coefficient estimations of lagged asset size $\left(\beta_{1}\right)$ could be inconsistent if growth persistence appears in the data. In these circumstances, even if the estimations of $\beta_{1}$ equal 1, Gibrat's law may not hold. To avoid the inconsistency problem, we test whether our data show a serial correlation bias. Using surviving firm data, we regress the growth rate of life insurers over the period 2002-2007 on the growth rate over the period 1996-2001. The coefficient for 1996-2001 is positive and insignificant. Moreover, the $R$-square value is very low (0.0092). Therefore, we have no evidence of growth persistence in our study. ${ }^{46}$

\section{Survivorship bias}

The sample attrition problem may arise in the firm size-growth model. When nonsurviving and small firms are excluded from the sample, the estimators of $\beta_{1}$ may be biased downward. Life insurers that fail to survive from 1996 to 2007 are nonsurviving firms. Without adjusting for survivorship bias, we could obtain a biased estimator. Heckman's ${ }^{18}$ two-stage regression provides an appropriate way to deal with this problem. ${ }^{47}$ We employ it to find the determinants of firm growth for life insurers in Taiwan. To carry out the regression, we use the probit survival equation to correct for sample selection bias. In the probit regression, binary survival (surviving firms $=1$; non-surviving firms $=0$ ) is the dependent variable. The inverse Mill's ratio estimated by residuals from the probit regression provides an additional independent variable in the second-stage regression in our model.

\section{Empirical results}

Using the two-stage regression method, we attain the empirical results for the determinants of a life insurer's growth for different periods and for domestic vs foreign insurers. We report the dynamic and static growth in Tables 6 and 7. The test of Gibrat's law indicates that the coefficients of lag size $\left(\beta_{1}\right)$ are significantly smaller than 1 in 2002-2007 and 1996-2007, but not significantly different from 1 in 1996-2001. Furthermore, we divide the sample into domestic and foreign life insurers, Gibrat's law does not hold during the entire period (1996-2007). If we use the average size instead of the lag size, we also find that small life insurers have higher growth rates than large ones. Generally speaking, our empirical results support that small life insurers achieve higher asset growth rates than large ones during our sample period in Taiwan, in contrast with Hardwick and Adams's and Choi's ${ }^{5,6}$ confirmations of Gibrat's law. Thus, it appears that Gibrat's law holds in developed countries, but as our empirical results show, it does not hold during a period of strong economic growth in Taiwan. We offer two potential reasons to explain why small life insurers might enjoy higher growth rates in Taiwan. First, during our sample period, strong economic

\footnotetext{
${ }^{46}$ In the growth persistence results, $g_{0}$ represents the 1996-2001 growth rate, and $g_{1}$ is the 2002-2007 growth rate (with standard errors in brackets): $g_{1}=1.39604+0.06788 g_{0}, R^{2}=0.0092$.

${ }^{47}$ Evans (1987b); Dunne and Hughes (1994); Hardwick and Adams (2002); Choi (2010).
} 
Table 6 Results of Heckman's two-stage regression for different periods

\begin{tabular}{|c|c|c|c|c|c|c|c|c|c|c|c|c|}
\hline \multirow[t]{3}{*}{ Independent variable } & \multicolumn{6}{|c|}{ Dynamic } & \multicolumn{6}{|c|}{ Static } \\
\hline & \multicolumn{2}{|c|}{$1996-2001$} & \multicolumn{2}{|c|}{$2002-2007$} & \multicolumn{2}{|c|}{$1996-2007$} & \multicolumn{2}{|c|}{$1996-2001$} & \multicolumn{2}{|c|}{$2002-2007$} & \multicolumn{2}{|c|}{$1996-2007$} \\
\hline & Coefficient & $\begin{array}{l}\text { Standard } \\
\text { error }\end{array}$ & Coefficient & $\begin{array}{l}\text { Standard } \\
\text { error }\end{array}$ & Coefficient & $\begin{array}{l}\text { Standard } \\
\text { error }\end{array}$ & Coefficient & $\begin{array}{l}\text { Standard } \\
\text { error }\end{array}$ & Coefficient & $\begin{array}{l}\text { Standard } \\
\text { error }\end{array}$ & Coefficient & $\begin{array}{l}\text { Standard } \\
\text { error }\end{array}$ \\
\hline Intercept & 0.5445 & 0.4273 & 2.2838 & $0.8066^{* * *}$ & 1.0269 & $0.3924 * * *$ & 3.3584 & $0.7673 * * *$ & 0.1133 & 0.7358 & 2.6770 & $0.5598 * * *$ \\
\hline Lag log size & 0.9853 & 0.0155 & 0.9416 & $0.0212 * * *$ & 0.9707 & $0.0120 * * *$ & - & - & - & - & - & - \\
\hline Age & -0.0034 & $0.0013^{* *}$ & -0.0010 & 0.0008 & -0.0028 & $0.0006 * * *$ & -0.0107 & $0.0045^{*}$ & -0.0043 & 0.0036 & -0.0060 & 0.0038 \\
\hline Profitability (current) & 1.3758 & $0.4967 * * *$ & 0.5074 & 0.7586 & 1.3890 & $0.4608 * * *$ & 2.6892 & $0.7087 * * *$ & -0.4010 & 1.6277 & 0.9996 & $0.4015^{* *}$ \\
\hline Profitability (lagged) & -1.0914 & 0.5853 & 0.1539 & 1.0608 & -0.9175 & 0.5663 & 1.9740 & $0.5384 * * *$ & 6.5376 & $1.3128 * * *$ & -0.3395 & 0.3107 \\
\hline Expense ratio (current) & 0.1280 & 0.1845 & -0.0753 & 0.2104 & 0.0221 & 0.1074 & -0.8994 & $0.2724 * * *$ & 0.3203 & 0.2717 & -0.9310 & $0.2111^{* * *}$ \\
\hline Expense ratio (lagged) & -0.0363 & $0.0381^{*}$ & -6.6499 & 7.1575 & -0.0382 & 0.0266 & -0.0498 & 0.07481 & -0.0738 & 0.2838 & 0.0406 & 0.0427 \\
\hline Product diversification & 0.3250 & $0.1550^{* *}$ & 0.3030 & $0.1357 * *$ & 0.3670 & $0.1066^{* * *}$ & 1.0359 & $0.3418 * * *$ & 0.6082 & $0.3226^{*}$ & -0.1868 & 0.3336 \\
\hline Cross-marketing & 0.0626 & $0.0367^{*}$ & 0.1237 & $0.0453^{* * *}$ & 0.0665 & $0.0293^{* *}$ & 0.1807 & 0.1488 & 0.0661 & 0.1376 & 0.0996 & 0.1047 \\
\hline Country & -0.0265 & 0.0467 & 0.0131 & 0.0249 & -0.0246 & 0.0263 & -0.0481 & 0.1087 & 0.0325 & 0.0935 & -0.0096 & 0.08917 \\
\hline Adjust $R$-square & \multicolumn{2}{|c|}{0.9879} & \multicolumn{2}{|c|}{0.9845} & \multicolumn{2}{|c|}{0.9888} & \multicolumn{2}{|c|}{0.8456} & \multicolumn{2}{|c|}{0.9058} & \multicolumn{2}{|c|}{0.9569} \\
\hline Observations & \multicolumn{2}{|c|}{119} & \multicolumn{2}{|c|}{141} & \multicolumn{2}{|c|}{260} & \multicolumn{2}{|c|}{119} & \multicolumn{2}{|c|}{141} & \multicolumn{2}{|c|}{260} \\
\hline
\end{tabular}

$* * *, * * *$ Significant at 1 per cent, 5 per cent and 10 per cent level respectively. 
Table 7 Results of Heckman's two-stage regression for domestic and foreign firms

\begin{tabular}{|c|c|c|c|c|c|c|c|c|}
\hline \multirow[t]{3}{*}{ Independent variable } & \multicolumn{4}{|c|}{ Dynamic } & \multicolumn{4}{|c|}{ Static } \\
\hline & \multicolumn{2}{|c|}{ Domestic firms } & \multicolumn{2}{|c|}{ Foreign firms } & \multicolumn{2}{|c|}{ Domestic firms } & \multicolumn{2}{|c|}{ Foreign firms } \\
\hline & Coefficient & $\begin{array}{l}\text { Standard } \\
\text { error }\end{array}$ & Coefficient & $\begin{array}{l}\text { Standard } \\
\text { error }\end{array}$ & Coefficient & $\begin{array}{l}\text { Standard } \\
\text { error }\end{array}$ & Coefficient & $\begin{array}{c}\text { Standard } \\
\text { error }\end{array}$ \\
\hline Intercept & 0.8756 & $0.3655^{* *}$ & 0.8609 & $0.5089^{*}$ & 4.4706 & $1.3577 * * *$ & 3.2237 & $0.0013 * * *$ \\
\hline Lag log size & 0.9595 & $0.0123 * * *$ & 0.9547 & $0.01866^{* * * *}$ & - & - & - & - \\
\hline Average log size & - & - & - & - & 0.7427 & $0.0859 * * *$ & 0.6836 & $0.0654 * * *$ \\
\hline Age & -0.0025 & $0.0006 * * *$ & 0.0032 & $0.0017^{*}$ & -0.0083 & 0.0055 & 0.0458 & $0.0096^{* * *}$ \\
\hline Profitability (current) & 1.0587 & $0.3127 * * *$ & 1.8474 & $0.5813^{* * *}$ & 2.9844 & $1.1839 * *$ & 2.8860 & $0.8418 * * *$ \\
\hline Profitability (lagged) & -0.4631 & 0.2295 & -0.8055 & 0.6691 & 2.6552 & $0.9721 * * *$ & 1.4702 & $0.6329 * * *$ \\
\hline Expense ratio (current) & 0.0182 & 0.1247 & 0.1085 & 0.1903 & -0.2991 & 0.3446 & -0.6084 & 0.4303 \\
\hline Expense ratio (lagged) & -3.5252 & 3.9486 & -0.0845 & $0.0423^{* *}$ & -1.0100 & $0.3054 * * *$ & -0.0385 & 0.0824 \\
\hline Product diversification & 0.0184 & 0.0947 & 0.8094 & $0.1910 * * *$ & -0.1825 & 0.4597 & 2.5514 & $0.4652 * * *$ \\
\hline Cross-marketing & 0.0383 & 0.0293 & 0.1551 & $0.0599^{* *}$ & -0.0040 & 0.2072 & 0.4932 & $0.2365^{* *}$ \\
\hline Inverse Mill's ratio & -8.4234 & 9.6153 & -0.6666 & 0.3291 & 0.0737 & 0.0349 & -0.0175 & 0.0228 \\
\hline Adjust $R$-square & \multicolumn{2}{|c|}{0.9924} & \multicolumn{2}{|c|}{0.9841} & \multicolumn{2}{|c|}{0.8406} & \multicolumn{2}{|c|}{0.8522} \\
\hline Observations & \multicolumn{2}{|c|}{140} & \multicolumn{2}{|c|}{120} & \multicolumn{2}{|c|}{140} & \multicolumn{2}{|c|}{120} \\
\hline
\end{tabular}

$* * *, * * *$ Significant at 1 per cent, 5 per cent and 10 per cent level respectively.

growth in Taiwan stimulated asset growth by small life insurers. Hardwick and Adams $^{5}$ also indicate that smaller life insurance firms grow faster than larger ones in booming macroeconomic situations. Second, as the Taiwanese government released entrance licenses more widely to new life insurers in 1990s, the asset value and annual premiums of new insurers significantly increased for that decade. Although our empirical results reject Gibrat's law, we could predict that this rejection is effective only in economies that are rapidly developing with a growing insurance market. A longer sample period, including both growth and recession eras, could reveal more support for Gibrat's law in Taiwan.

Regardless of which sample periods we consider, we find a negative relationship between firm age and firm growth (significant in the first sub-period and entire period). Our empirical results are consistent with previous studies, ${ }^{21}$ young firms grow faster than old firms. However, our empirical results also provide some complex findings related to an inverse relationship between firm age and firm growth for domestic life insurers, but not for foreign insurers in Taiwan. This empirical result may be due to two reasons. First, there is no significant difference in firm age among most of foreign insurers because the Taiwan government opened insurance market to them until 1987, yet foreign firms with slightly older ages enjoy a positive growth relationship because they have more experience and are more familiar with the market than are younger foreign firms. Furthermore, the foreign insurers who obtained the initial licenses and entered Taiwan market usually have advantages of financial support and brand reputation because they have superior parent companies prepared to expand their business overseas. For the first sub-period and the entire period, we note a positive and significant relationship between asset growth and current profitability. We find the same results for both domestic and foreign life insurers. Current profitability plays an important role in determining a life insurer's growth rate in Taiwan; 
this empirical result again is consistent with some previous studies. ${ }^{48}$ Firms with more profitability might expand their market share and use their earnings to proceed with more efficient asset allocations. Consistent with prior literature, we find empirically, in support of our prediction, that life insurance companies with higher expense ratios grow more slowly. A higher expense ratio implies that cost inefficiency relates to disproportionate economies of scale or a misallocation of resources. Furthermore, cost inefficiency and resource misallocations impede asset growth in the next period. In Taiwan, because foreign life insurers in general have smaller scale and fewer resources to expand their business, their asset growth rate could be stagnant if they cannot efficiently reduce their expense ratio. Our empirical evidence also supports that the expense ratio is significant across domestic and foreign firms, dynamic and static models, current and lagged variables, in different periods. Therefore, especially for foreign firms, ways to reduce expense ratios are meaningful inputs as determinants of a life insurer's growth.

The coefficients of the product diversification variable are positive and significant in most of sample periods. The positive and significant relationship only exists for foreign insurers though, not for domestic insurers. Foreign insurers adjust their diversified strategies and gradually have concentrated on specialised products over time, because they found a competitive advantage through investment-link products. The average product diversification of foreign insurers increased over time, and these empirical results support previous findings related to the diversification discount hypothesis. However, we cannot confirm this phenomenon among domestic life insurers. Our finding is consistent with prior studies that local insurers have more resources to develop their business than foreign insurers. ${ }^{49}$ That is, domestic and foreign insurance firms show some different determinants of asset growth.

The coefficients for the cross-marketing dummy variable are positive in all periods (significant in lag size model, but insignificant in average size model). Our empirical result in the time-varying model is consistent with Choi's ${ }^{6}$ finding: Life insurers in a financially affiliated group tend to enjoy higher growth. The beta coefficient of crossmarketing is positive and significant for foreign life insurers but not for domestic ones. Because nearly 30 per cent of the domestic firms already use cross-marketing channels to promote their products, it does not appear to offer much of a comparative advantage to them. However, using the consumer lists and resources of other companies could be an excellent way for foreign firms to increase their asset growth. In contrast, the coefficients for the country dummy variable are insignificant in all periods. Domestic life insurers do not grow faster than foreign life insurers in Taiwan. Even though insurers from different countries have various management styles and cultural backgrounds, there is no evidence that significantly different asset growth distinguishes them.

Finally, more experienced and flexible market strategies are advantageous for foreign companies, compared with domestic companies in developing country market. Domestic life insurers often follow the developed countries' paths, but they still reveal some differences. Foreign life insurers offer some inspiration in terms of product

\footnotetext{
${ }^{48}$ For example, Sommer (1996); Geroski et al. (1997); Cummins and Nini (2002); Elango et al. (2008).

49 Yao et al. (2007); Chen et al. (2009).
} 
design, actuarial methodologies, ALM and service styles. For example, Aetna Life International issued the first unlimited coverage medical product in 1997 and added new clauses to its life insurance contract. In summary, our empirical results reveal that firm growth for both domestic and foreign life insurers offers no support for Gibrat's law in Taiwan. Moreover, we find different firm growth patterns between these two groups of life insurers.

\section{Conclusions}

The link between asset growth and firm size has been a frequent topic of interest for practice and academia. Most previous studies investigate determinants of growth with data from developed countries. However, the life insurance industry in developing countries is growing increasingly important due to their booming economies. We investigate determinants of life insurers' growth in the developing insurance market in Taiwan. Particularly, we focus on domestic vs foreign insurance firms. As Taiwan's insurance industry has grown significantly in the past decade, the annual premiums sold rank ninth in the world, and insurance penetration achieved first place as of 2009. Taiwan also represents an important insurance market among developing countries in Asia. Our empirical analysis illustrates its life insurance industry for the period 1996-2007 and thereby achieves two main research goals. We investigate the relationship between firm growth and firm characteristics for this life insurance industry and test Gibrat's law. Furthermore, we distinguish different growth patterns between domestic and foreign life insurers. Using a sample of 260 firm-years during 1996-2007, as well as in two sub-periods, we test for any time-varying effects. Our empirical results, based on Heckman's two-stage methodology, indicate that Gibrat's law does not hold for our sample. The robustness check of firms divided into two groups, domestic and foreign insurers, reconfirms this finding: Regardless of their country of origin, small life insurers attain greater growth rates than large life insurers. Our data reflect a fast growing economy, and we thus concur with Hardwick and Adams ${ }^{5}$ that Gibrat's law should be rejected during high growth periods. After the Taiwan insurance market began to open in the 1990s, the underwriting profit cycle remained positive and expanding. Smaller insurers have a greater probability of growth in the early period of market opening, through the expansion of their underwriting profit. This phenomenon could explain why foreign insurers are so aggressive and active in entering the insurance market in developing countries. In other words, small-size insurers could enjoy higher asset growth rates than large-size insurers during the market-opening period in developing countries. This booming underwriting profit cycle also might explain our rejection of Gibrat's law. A recessionary underwriting profit cycle period thus would provide an interesting test of whether Gibrat's law holds in developing countries. We recommend that further research undertake an empirical study with a longer period and more developing countries.

In addition to previous asset size, factors such as firm age, current profitability, lagged expense ratio, product diversification and cross-marketing play prominent roles as determinants of life insurer asset growth in Taiwan. Our empirical results confirm that young firms grow faster than old ones. Firms with more profitability use their 
earnings more efficiently and thereby achieve higher growth than firms with lower profitability. Greater expense ratios also impede asset growth in the next period. Thus, the ways to increase the profits and reduce the expense ratio of insurers are meaningful inputs as determinants of a life insurer's asset growth. If life insurers focus on more specialised products, they might encourage growth. Cross-marketing with financial affiliates also can stimulate asset growth. Our empirical results reveal that different factors influence the growth of domestic and foreign life insurers in Taiwan. In particular, lagged asset size, age and current profitability are determinants of growth. When domestic firms are smaller, younger and more profitable, their growth rate increases. The lagged asset size, firm age, current profitability, product diversification and cross-marketing variables also determine foreign life insurers' growth: Small, older foreign life insurers enjoy higher growth rates. Higher profitability and lower expense ratios stimulate asset growth, as does a focus on specialised products and the use of cross-marketing.

Our study thus provides some implications for the insurance operations of domestic and foreign life insurers separately. The governments of developing countries have gradually opened their insurance markets to foreign firms in recent years. Initially, domestic life insurers may have to face changes and more challenges from foreign competitors. At this time, the supervisors of developing countries may enact some regulations regarding foreign insurers' operations (e.g. limitations of business, to compel foreign firms to establish joint venture companies). However, the governments of developing countries should withdraw such limitations eventually because domestic and foreign insurers have distinct determinants of asset growth. For the insurance industry, domestic and foreign insurers should develop their business in accordance with their unique competitive advantages, because the determinants of their growth differ. Domestic life insurers already are larger, more resource rich and more familiar with the local market than are foreign life insurers. However, foreign life insurers should exploit their advantages based on their innovations in product design, risk management and asset allocation, and modern information technology.

With this research, we answer the question of whether small insurers grow as quickly as large ones. Even with these interesting findings, we note some areas for further research. First, property-liability insurers in developing countries could exhibit different features than life insurers, because of their unique patterns of cash flow, contingent claims and reinsurance. Determinants of property-liability insurers' asset growth in developing countries therefore should be distinguished separately. Second, the test for Gibrat's law could be extended to a longer period, to include recessionary periods, and thus investigate the expansion of underwriting profit cycles in developing countries further.

\section{References}

Alhadeff, D. and Alhadeff, C. (1964) 'Growth of large banks, 1930-1960', Review of Economics and Statistics 46(4): $356-363$.

Ambrose, J.M. and Seward, J.A. (1988) 'Best's ratings financial ratios and prior probabilities in insolvency prediction', The Journal of Risk and Insurance 55(2): 229-244. 
Audretsch, D., Klomp, L., Santarelli, E. and Thurik, A. (1997) Do services differ from manufacturing? The post-entry performance of firms in Dutch services, Discussion Paper No.1718, Center for Economic Policy Research.

Audretsch, D., Klomp, L., Santarelli, E. and Thurik, A. (2004) 'Gibrat's law: Are the services different?' Review of Industrial Organization 24(3): 301-324.

BarNiv, R. and Hershbarger, R.A. (1990) 'Classifying financial distress in the life insurance industry', Journal of Risk and Insurance 57(1): 110-136.

Berger, A.N., Cummins, J.D. and Weiss, M.A. (1997) 'The coexistence of multiple distribution systems for financial services: The case of property-liability insurance', The Journal of Business 70(4): 515-546.

Berger, P.G. and Ofek, E. (1995) 'Diversification's effect on firm value', Journal of Financial Economics 37(1): 39-65.

Calvo, J.L. (2006) 'Testing Gibrat's law for small, young and innovating firms', Small Business Economics 26(2): 117-123.

Chen, B., Powers, M.R. and Qiu, J. (2009) 'Life-insurance efficiency in China: A comparison of foreign and domestic firms', China and World Economy 17(6): 43-63.

Chen, R. and Wong, K.A. (2004) 'The determinants of financial health of Asian insurance companies', The Journal of Risk and Insurance 71(3): 469-499.

Chen, R., Wong, K.A. and Lee, H.C. (1999) 'Underwriting cycles in Asia', The Journal of Risk and Insurance 66(1): 29-47.

Chesher, A. (1979) 'Testing the law of proportionate effect', The Journal of Industrial Economics 27(4): 403-411.

Choi, B.P. (2010) 'The U.S. property and liability insurance industry: Firm growth, size and age', Risk Management and Insurance Review 13(2): 207-224.

Choi, B.P. and Weiss, M.A. (2005) 'An empirical investigation of market structure, efficiency, performance in property-liability insurance', The Journal of Risk and Insurance 72(4): 635-673.

Cummins, J.D. and Nini, G. (2002) 'Optimal capital utilization by financial firms: Evidence from the property-liability insurance industry', Journal of Financial Services Research 21(1): 15-53.

Cummins, J.D., Weiss, M.A. and Zi, H. (1999) 'Organizational form and efficiency: The coexistence of stock and mutual property-liability insurers', Management Science 45(9): 1254-1269.

Dunne, P. and Hughes, A. (1994) 'Age, size and survival: UK companies in the 1980s', The Journal of Industrial Economics 42(2): 115-140.

Elango, B., Ma, Y.L. and Pope, N. (2008) 'An investigation into the diversification-performance relationship in the U.S. property-liability insurance industry', The Journal of Risk and Insurance 75(3): 567-591.

Evans, D.S. (1987a) 'Tests of alternative theories of firm growth', Journal of Political Economy 95(4): 657-674

Evans, D.S. (1987b) 'The relationship between firm growth, size, and age: Estimates for 100 manufacturing industries', The Journal of Industrial Economics 35(4): 567-581.

Geroski, P., Lazarova, S., Urga, G. and Walters, C. (2003) 'Are the differences in firm size transitory or permanent?' Journal of Applied Econometrics 18(1): 47-59.

Geroski, P. and Machin, S. (1993) 'The dynamics of corporate growth', unpublished manuscript, London Business School.

Geroski, P.A., Machin, S.J. and Walters, C.F. (1997) 'Corporate growth and probability', Journal of Industrial Economics 45(2): 171-189.

Gibrat, R. (1931) Les Inequalites Economiques, Paris: Librairie du Recueil Sirey.

Goddard, J., Molyneux, P.M. and Wilson, J.O. (2004) 'Dynamics of growth and profitability in banking', Journal of Money, Credit and Banking 36(6): 1069-1090.

Goddard, J., Wilson, J. and Blandon, P. (2002) 'Panel test of Gibrat's law for Japanese manufacturing', International Journal of Industrial Organization 20(3): 415-433.

Gujarati, D.N. (1995) Basic Econometrics, 3rd edn. New York: McGraw-Hill.

Hall, B.H. (1987) 'The relationship between firm size and firm growth in the US manufacturing sector', The Journal of Industrial Economics 35(4): 583-606.

Hamilton, O., Shapiro, D. and Vining, A. (2002) 'The growth patterns of Canadian high-tech firms', International Journal of Technology Management 24(4): 458-472.

Hao, J.C. (2009) The evaluation of economic efficiency under the consideration of quasi-fixed inputs: The case in Taiwan's life insurance industry, working paper. 
Hardwick, P. and Adams, M. (2002) 'Firm size and growth in the United Kingdom life insurance industry', The Journal of Risk and insurance 69(4): 577-593.

Harhoff, D., Stahl, K. and Woywode, M. (1998) 'Legal form, growth and exit of West German firmsempirical results for manufacturing, construction, trade and service industries', The Journal of Industrial Economics 46(4): 453-488.

Heckman, J. (1979) 'Sample selection bias as a specification error', Econometrica 47(1): 153-161.

Jovanovic, B. (1982) 'Selection and the evolution of industry', Econometrica 50(3): 649-670.

Lai, G.C. and Limpaphayom, P. (2003) 'Organizational structure and performance: Evidence from the nonlife insurance industry in Japan', The Journal of Risk and Insurance 70(4): 735-757.

Li, D. and Moshirian, F. (2004) 'International investment in insurance services in the US', Journal of Multinational Financial Management 14(3): 249-260.

Mayers, D. and Smith Jr., C.W. (1988) 'Ownership structure across lines of property-casualty insurance', Journal of Law and Economics 31(2): 351-378.

Mueller, E. (2008) 'Benefits of control, capital structure and company growth', Applied Economics 40(21): 2721-2734.

Rhoades, S.A. and Yeats, A.J. (1974) 'Growth, consolidation and mergers in banking', The Journal of Finance 29(5): 1397-1405.

Santomero, A.M. and Babbel, D.F. (1997) 'Financial risk management by insurers: An analysis of the process', The Journal of Risk and Insurance 64(2): 231-270.

Sommer, D.W. (1996) 'The impact of firm risk on property-liability insurance prices', The Journal of Risk and Insurance 63(3): 501-514.

Tschoegl, A.E. (1983) 'Size, growth, and transnationality among the world's largest banks', The Journal of Business 56(2): 187-201.

Webster, Jr., F.E. (1992) 'The changing role of marketing in the corporation', Journal of Marketing 56(4): $1-17$.

Weiss, C.R. (1998) 'Size, growth, and survival in the upper Austrian farm sector', Small Business Economics 10(4): 305-312.

White, H. (1980) 'A heteroskedasticity-consistent covariance matrix estimator and a direct test for heteroskedasticity', Econometrica 48(4): 817-838.

Whittington, G. (1980) 'The profitability and size of United Kingdom companies 1960-1974', The Journal of Industrial Economics 28(4): 335-352.

Yao, S., Han, Z. and Feng, G. (2007) 'On technical efficiency of China's insurance industry after the WTO accession', China Economic Review 18(1): 66-86.

Yasuda, T. (2005) 'Firm growth, size, age and behavior in Japanese manufacturing', Small Business Economics 24(1): 1-15.

Ye, D., Li, D., Chen, Z., Moshirian, F. and Wee, T. (2009) 'Foreign participation in life insurance markets: Evidence from OECD countries', The Geneva Papers on Risk and Insurance: Issues and Practice 34(3): 466-482.

Yeats, A.J., Irons, E.D. and Rhoades, S.A. (1975) ‘An analysis of new bank growth', The Journal of Business 48(2): 199-203.

\section{About the Authors}

Joseph J. Tien is Assistant Professor of the Department of Insurance at Tamkang University, Taiwan. He teaches insurance, asset and liability management and corporate finance. Dr Tien's research focuses on the areas of asset and liability management, health insurance programmes and insurance finance.

Sharon S. Yang is Professor and the Chairperson of the Department of Finance at National Central University, Taiwan. Her research interests cover risk management, actuarial science, longevity modeling and securitization. 